\title{
Thromboelastography in healthy dairy cows
}

\author{
Cora-Costanze Sommerey, ${ }^{1,2}$ Tim L. Williams, Ian McCrone, Aran Ruiz-Ferreras, Dan Freeman, \\ and Joy Archer \\ Department of Veterinary Medicine, University of Cambridge, Cambridge CB3 0ES, United Kingdom
}

\begin{abstract}
Thromboelastography is a whole blood-based coagulation assay that can be used to investigate hypocoagulability and hypercoagulability, as seen with thromboembolic diseases and disseminated intravascular coagulation. Numerous coagulopathies due to different causes are reported in cows. The objective was to establish reference intervals for thromboelastography using the TEG 5000 (Haemonetics GmbH, Munich, Germany) with citrated whole blood samples and kaolin activation in dairy cows and to investigate possible thromboelastographic changes between cows in different lactation periods. An additional objective was to test the stability of samples for up to $100 \mathrm{~h}$. Sixty blood samples from healthy Holstein-Friesian cows were examined. The samples were allocated to 3 different lactation groups ( $\leq 30 \mathrm{~d}$ postcalving, 31-99 d postcalving, $\geq 100$ d postcalving). Thromboelastography was performed by using the TEG 5000 analyzer with citrated whole blood samples with kaolin activation. The calculated reference intervals were as follows: reaction time $=2.2$ to $6.2 \mathrm{~min}$, coagulation time $=0.8$ to $2.0 \mathrm{~min}$, angle $\alpha=58.2$ to $81.8^{\circ}$, maximum amplitude $=64.3$ to 89.2 $\mathrm{mm}$, and clot rigidity $=9.2$ to $41.2 \mathrm{dyn} / \mathrm{cm}^{2}$. The 3 different lactation groups showed no significant differences in TEG parameters. No significant difference was seen in samples stored for up to $48 \mathrm{~h}$ at room temperature, which indicates that delays in processing samples, such as those arising during transit, are not an issue.
\end{abstract}

Key words: bovine, coagulation, lactation, reference interval, thromboelastography

\section{INTRODUCTION}

Hemostasis is the arrest of bleeding from an injured blood vessel; it requires the combined activity of vascular, platelet, and plasma factors, with regulatory mechanisms to counterbalance the tendency of clots to

Received January 6, 2014.

Accepted June 2, 2014.

${ }^{1}$ Current address: Laboklin GmbH \& Co. KG, Steubenstrasse 4, D-97688 Bad Kissingen, Germany.

${ }^{2}$ Corresponding author: Sommerey@laboklin.de form. For assessment of hemostasis, coagulation profiles are assessed, including platelet count; fibrinogen concentration; the coagulation times prothrombin time (PT), activated partial thromboplastin time (APTT), and thrombin clotting time (TCT); and single coagulation factors, as well as thromboelastography.

Thromboelastography is a whole blood-based assay used in human and veterinary medicine for evaluation of primary hemostasis, including thrombocytopenia and thrombocytopathy, as well as secondary hemostasis, as seen with hemophilia. Additionally, it is applied to detect hypercoagulability to identify prethrombotic changes, especially early diagnosis of disseminated intravascular coagulation (DIC; Donahue and Otto, 2005).

Thromboelastography was first developed by Hartert (1948) to evaluate the coagulation of whole blood. The method assesses the speed and strength of blood clot formation in vitro and is thought to better represent in vivo hemostasis than plasma-based assays (Flint et al., 2011). The principle of the technique is monitoring the gradual binding of a pin to the sides of a cup during clot formation and displaying this as a graph (Wiinberg and Kristensen, 2010). Thromboelastography is routinely performed on citrated whole blood that, after recalcification, is activated using recombinant human tissue factor or kaolin, or is run native (without activation; Wiinberg and Kristensen, 2010). It is recommended that analysis of the blood samples be performed between 30 min and $2 \mathrm{~h}$ postsampling (Kol and Borjesson, 2010; Wiinberg and Kristensen, 2010).

Currently, 2 different analyzers are used worldwide: a thromboelastograph (TEG; TEG 5000, Haemonetics GmbH, Munich, Germany) and a rotational thromboelastometer (ROTEM; Tem International GmbH, Munich, Germany). The equipment differs in that the TEG has an oscillating cup, whereas the ROTEM has a rotating pin (Wiinberg and Kristensen, 2010). Both analyzers measure the same variables but using different terminology (Kol and Borjesson, 2010). The parameters assessed (in TEG terminology) consist of reaction time $(\mathbf{R})$, which is the time in minutes from clot initiation until the first fibrin polymers are produced, clot formation time $(\mathbf{K})$, the angle $(\boldsymbol{\alpha})$ reflecting 
the kinetics of fibrin formation and crosslinking, and maximal clot strength (MA), which is displayed as the maximum amplitude in millimeters. Clot rigidity $(\mathbf{G})$ is a modification of MA to physical units (Kol and Borjesson, 2010).

Comparison of the proprietary activation (kaolin for TEG; partial thromboplastin phospholipids for ROTEM) revealed significant differences between the representative single parameters; therefore, single parameter results are not directly comparable (Nielsen, 2007). This also applies to the different activation modes; therefore, separate validations are necessary for both analyzers and for the specific activation mode (Wiinberg and Kristensen, 2010).

Validations of thromboelastography with TEG and ROTEM in numerous species have been performed. Furthermore, studies using thromboelastography to investigate coagulopathies and other clinical conditions have been reported (Kol and Borjesson, 2010). Hypercoagulable states (e.g., due to DIC) could be identified in these studies.

Several bleeding disorders have been described in cattle (Bell, 2011), and hemostasis has been investigated. Reference intervals for coagulation parameters PT, APTT, TCT, and fibrinogen have been established for healthy cattle (Heuwieser et al., 1989), as has that for activated coagulation time (Riley and Lassen, 1979). Wittek et al. (2010) investigated the fibrin degradation products D-dimers in healthy cows, to assess increased fibrinolysis associated with coagulation, as seen with DIC.. The coagulation profile remained stable during pregnancy and parturition in the study by Gentry et al. (1979) but showed hypercoagulability in the periparturient period ( $3 \mathrm{~d}$ before and $2 \mathrm{~d}$ after), as revealed by shorter PT and partial thromboplastin times in the study by Heuwieser et al. (1990a). Fibrinogen values showed no significant differences between pregnant and nonpregnant cows (McSherry et al., 1970; Gentry et al., 1979; Schlerka and Baumgartner, 1994), unlike in the study of Heuwieser et al. (1990b), which reported significantly increased fibrinogen levels within the last 3 d before calving. Schlerka and Baumgartner (1994) found a significantly shorter APTT in pregnant compared with nonpregnant cows due to increased activity of factor IX.

Several of these coagulation studies in bovine species were coagulation factor-based, but thromboelastometry using ROTEM has recently been validated for cattle (Falco et al., 2012). The study population was mixed, including 14 male Holstein-Friesian calves, 15 Piedmontese cows, and 33 bulls (Holstein-Friesian, Charolais, and Piedmontese). Reference intervals were created for healthy adult cattle and calves; peripartal cows (1 mo before and after calving) were excluded (Falco et al.,
2012). One study in calves has used thromboelastography (ROTEM) to investigate the hemostatic effect caused by low doses of dexamethasone (Borrelli et al., 2013).

The aim of this study was to validate thromboelastography for cows using kaolin-activated TEG analysis and to create reference intervals. An additional objective was to assess significant differences between different lactation states, including peripartal cows. Finally, we aimed to evaluate the stability of samples to allow submission of samples via courier, thus, making this test available to the general practitioner.

\section{MATERIALS AND METHODS}

The samples were taken from cows from the university farm (Cambridge, UK), a 240-cow Holstein-Friesian commercial dairy unit, where cows were milked using automatic milking system (robots) and housed yearround in cubicles (freestalls). Cows were fed a mixed ration comprising mainly grass silage and a concentrate feed in the milking machine according to milk yield. Between July 2012 and March 2013, samples were made available as excess blood taken from cows undergoing metabolic profiling for health and production as part of the dairy herd health plan. This involved sampling of cows in early lactation (up to $30 \mathrm{~d}$ ), at peak lactation $(60$ to $90 \mathrm{~d})$, and past peak lactation. For this health check, 2 blood samples from each cow were taken from the coccygeal vein, consisting of one $10-\mathrm{mL}$ serum tube and one 5-mL sodium citrate tube. Samples were chosen from 60 cows that were diagnosed as healthy according to the results from clinical examination, hematology, and biochemistry results.

The citrate blood samples, used for hematology, coagulation, and thromboelastography, were drawn first to minimize possible tissue factor contamination; correct filling of the tubes as well as evidence of clots in the sample were checked. Thromboelastography was carried out after hematology using the remaining citrate whole blood sample. Testing of coagulation times followed, performed with citrate plasma, obtained by centrifugation.

Thromboelastography was performed using the TEG 5000 (Haemonetics $\mathrm{GmbH}$ ) exclusively by one of the authors (C.-C. S.). The age of the cows ranged from 2 to $10 \mathrm{yr}$ with a mean and median of $5 \mathrm{yr}$. The cows were grouped according to their calving date $(\mathrm{A}=\leq 30$ $\mathrm{d}$ postcalving, $\mathrm{B}=31-99 \mathrm{~d}$ postcalving, $\mathrm{C} \geq 100 \mathrm{~d}$ postcalving). Twenty-four cows were classified into group A, 16 cows into group B, and 20 cows into group C. Of these 60 cows, 15 cows ( 4 from group B and 11 from group $\mathrm{C}$ ) were pregnant with a mean of $88 \mathrm{~d}$, median of $82 \mathrm{~d}$, and ranging from 1 to $238 \mathrm{~d}$ (Table1). 
Table 1. Study population and subgroups of 60 healthy dairy Holstein-Friesian cows classified into lactation groups $(\mathrm{A}=\leq 30 \mathrm{~d}$ postcalving, $\mathrm{B}$ =31-99 d postcalving, $\mathrm{C}=\geq 100 \mathrm{~d}$ postcalving)

\begin{tabular}{|c|c|c|c|c|c|c|c|c|c|}
\hline \multirow[b]{2}{*}{ Group } & \multicolumn{3}{|c|}{ Age (yr) } & \multicolumn{3}{|c|}{ Days postcalving } & \multicolumn{3}{|c|}{ Milk yield (kg/d) } \\
\hline & Mean & Median & Range & Mean & Median & Range & Mean & Median & Range \\
\hline $\mathrm{B}(\mathrm{n}=16)$ & 5.3 & 5.6 & $2-9$ & 75.8 & 85.0 & 35-99 & 33.9 & 32.1 & $10.4-52.4$ \\
\hline $\mathrm{C}(\mathrm{n}=20)$ & 4.9 & 4.4 & $3-8$ & 220.1 & 152.0 & $102-545$ & 25.7 & 25.0 & $10.2-43.5$ \\
\hline Total & 4.8 & 4.5 & $2-10$ & 99.6 & 75.5 & $0-545$ & 29.9 & 29.9 & $10.2-52.4$ \\
\hline
\end{tabular}

\section{Thromboelastography}

Thromboelastography was performed with recalcified citrated whole blood using the TEG 5000 analyzer according to the manufacturer's recommendations. Samples were run within $2 \mathrm{~h}$ postsampling and were stored during this time at room temperature. Pins and cups were placed in the analyzer according to instructions. Twenty microliters of $0.2 \mathrm{M} \mathrm{CaCl}$ was added to the cups. A tube containing kaolin (Haemonetics $\mathrm{GmbH}$ ) was filled with $1 \mathrm{~mL}$ of citrated whole blood sample. The tube was mixed by gentle inversion 5 times. Then, $340 \mu \mathrm{L}$ of kaolin citrate whole blood mixture was added to the $\mathrm{CaCl}$ in the cup and the TEG was started immediately. Reaction time (R), coagulation time $(\mathrm{K})$, angle $\alpha(\alpha)$, maximum amplitude (MA), and clot rigidity $(\mathrm{G})$ were assessed in a 90-min run.

\section{Stability Test}

Thromboelastography was first developed to investigate coagulation using fresh whole blood within $6 \mathrm{~min}$, ideally at the 4-min stage (Bowbrick et al., 2000). The time span between sampling and testing was increased by using citrated whole blood to up to $2 \mathrm{~h}$ (Wiinberg and Kristensen, 2010). To test whether storage time could be increased further, to make this test more widely available, especially for courier or mail samples, additional runs, whenever possible, were performed. Overall, 28 of the 60 samples which were stored at room temperature, could be run a second time after $>16 \mathrm{~h}$ $(16-77 \mathrm{~h})$, and 7 samples were run a third time $(32-100$ h). Storage times ranged from 16 to $100 \mathrm{~h}$ postsampling. The samples were allocated to 2 time groups (1: $\leq 48 \mathrm{~h}$ and 2: $>48 \mathrm{~h}$; Table 2).

\section{Statistics}

The reference intervals were calculated automatically using the Reference Value Advisor V2 (Geffré et al., 2011). The software tested normality according to Anderson-Darling. Additionally, a generalized Box-Cox transformation was performed. Dixon-Reed and Tukey tests were used to test for outliers. Nonparametric refer- ence intervals were calculated, and confidence intervals were determined by using a nonparametric bootstrap method.

The sample size was large enough to compute a nonparametric reference interval. The confidence intervals of the limits of the nonparametric reference interval were determined using a bootstrap method. Clinicopathological and coagulation variables of interest were also compared between the 3 lactation groups (according to calving date) using the Kruskal-Wallis test, with statistical significance defined as $P<0.05$. Post hoc testing was performed using the Mann-Whitney U test with Bonferroni correction applied to adjust for multiple comparisons; hence, $P<0.017$ was regarded as statistically significant in post hoc testing.

For stability test results, normality was tested using the Shapiro-Wilk test. Thromboelastography parameters at $2 \mathrm{~h}$ were compared between the 2 time groups (1 and 2) using the Wilcoxon signed ranks test, and statistical significance was defined as $P<0.05$.

\section{RESULTS AND DISCUSSION}

By thromboelastography, the following mean TEG values were obtained for Holstein-Friesian dairy cattle: $\mathrm{R}=4.0 \mathrm{~min}, \mathrm{~K}=1.1 \mathrm{~min}$, angle $\alpha=74.2^{\circ}, \mathrm{MA}=$ $82.3 \mathrm{~mm}$, and $\mathrm{G}=25.3 \mathrm{dyn} / \mathrm{cm}^{2}$. Parameters $\mathrm{R}$ and $\mathrm{G}$ showed a normal distribution. Reference intervals for citrated kaolin-activated TEG were calculated and are shown in Table 3.

Thromboelastography in cows has been validated for the ROTEM thromboelastometer (Falco et al., 2012). However, ROTEM results are not directly comparable with or transferable to the TEG results (Nielsen, 2007), and the study population in the current study was markedly different from that in the Falco et al. (2012)

Table 2. Grouping in 2 time groups according to sample storage times (h) with mean, median, and range

\begin{tabular}{lccl}
\hline Time group & Mean & Median & Range \\
\hline $1: \leq 48 \mathrm{~h}(\mathrm{n}=26)$ & 24.7 & 22.0 & $16-46$ \\
$2:>48 \mathrm{~h}(\mathrm{n}=11)$ & 68.3 & 67.0 & $50-100$ \\
\hline
\end{tabular}


Table 3. Calculated reference intervals for kaolin-activated thromboelastography parameters determined in recalcified citrated whole blood $(\mathrm{n}=60$ healthy cows), assessed using Reference Value Advisor V2 (Geffré et al., 2011)

\begin{tabular}{|c|c|c|c|c|c|}
\hline \multirow[b]{2}{*}{ Parameter $^{1}$} & \multirow{2}{*}{$\begin{array}{l}\text { Distribution } \\
\text { of data }\end{array}$} & \multicolumn{2}{|c|}{ Reference limit } & \multicolumn{2}{|c|}{$90 \%$ CI interval } \\
\hline & & Lower & Upper & Lower & Upper \\
\hline $\mathrm{R}(\min )$ & Gaussian & 2.2 & 6.2 & $2.1-2.3$ & $5.6-6.5$ \\
\hline $\mathrm{K}(\min )$ & Non-Gaussian & 0.8 & 2.0 & $\mathrm{ND}^{2}$ & $1.7-2.2$ \\
\hline Angle $\alpha$ & Non-Gaussian & 58.2 & 81.8 & $55.5-63.0$ & $80.6-82.1$ \\
\hline $\mathrm{MA}(\mathrm{mm})$ & Non-Gaussian & 64.3 & 89.2 & ND & $88.4-90.0$ \\
\hline $\mathrm{G}\left(\mathrm{dyn} / \mathrm{cm}^{2}\right)$ & Gaussian & 9.2 & 41.2 & $7.2-12.9$ & $37.2-43.0$ \\
\hline
\end{tabular}

study. Although the animals in the study from Falco et al. (2012) were mixed regarding breed, sex, and age, our population comprised adult Holstein-Friesian dairy cattle only.

Additionally, reference intervals in thromboelastography depend on the method used, including sample type (fresh or citrated whole blood) and which activators, if any, are used (native, kaolin, or recombinant human tissue factor) as the parameters are significantly different (Marschner et al., 2010; Banerjee et al., 2011; Flint et al., 2012; Hyldahl Laursen et al., 2013). Therefore, the reference intervals determined in this study can be compared only with studies using the TEG 5000 analyzer with citrated whole blood and kaolin as activator. This method has been performed in dogs, cats, horses, and pigtail macaques, with sample numbers ranging from 6 to 56 (Bauer et al., 2009; Marschner et al., 2010; Banerjee et al., 2011; Flint et al., 2012; Fong et al., 2012; Hyldahl Laursen et al., 2013). The reference intervals are shown in Table 4. Compared with those of other species, the parameters for cows have narrower reference intervals, with shorter $\mathrm{R}$ and $\mathrm{K}$ times, higher angle $\alpha$, and notably higher MA and G values (Table 4).

Overall, similar observations were made in the study of Falco et al. (2012) using the ROTEM thromboelastometer in cows and comparing their study results with equivalent studies in horses and dogs performed on the ROTEM thromboelastometer.

\section{Comparison of Different Lactation Groups}

The TEG parameters (R, K, $\alpha, M A$, and $G$ ), packed cell volume, or coagulation times PT and APTT did not differ significantly between groups A, B, and C (Tables 5 and 6 ). Only plasma protein was significantly different between groups A and B $(P<0.017)$. Plasma protein, fibrinogen, and plasma protein:fibrinogen ratio were significantly different between groups $\mathrm{A}$ and $\mathrm{C}$ $(P<0.017$; Table 6$)$. Because of the small number of pregnant cows $(\mathrm{n}=15)$, assessment of significant differences between pregnant and nonpregnant cows was not possible.

Table 4. Comparison of kaolin-activated thromboelastography parameter reference intervals for cows, dogs, cats, horses, and pigtail macaques, determined in recalcified citrated whole blood

\begin{tabular}{|c|c|c|c|c|c|}
\hline \multirow[b]{2}{*}{ Species } & \multirow[b]{2}{*}{ Reference $^{1}$} & \multicolumn{4}{|c|}{ Parameter $^{2}$} \\
\hline & & $\mathrm{R}(\min )$ & $\mathrm{K}(\min )$ & Angle $\alpha\left(^{\circ}\right)$ & $\mathrm{MA}(\mathrm{mm})$ \\
\hline Cows & $\begin{array}{l}\text { This study } \\
(\mathrm{n}=60)(\mathrm{ST}:<2 \mathrm{~h})\end{array}$ & $2.2-6.2$ & $0.8-2.0$ & $58.2-81.8$ & $64.3-89.2$ \\
\hline \multirow[t]{2}{*}{ Dogs } & $\begin{array}{l}\text { Bauer et al. }(2009) \\
(\mathrm{n}=56)(\mathrm{ST}: 1 \mathrm{~h})\end{array}$ & $1.8-8.6$ & $1.3-5.7$ & $36.9-74.6$ & $42.9-67.9$ \\
\hline & $\begin{array}{l}\text { Flint et al. }(2012) \\
(\mathrm{n}=40)(\mathrm{ST}: 30 \mathrm{~min})\end{array}$ & $1.7-6.1$ & $1.0-3.4$ & $48.5-75.2$ & $46.1-64.2$ \\
\hline \multirow[t]{2}{*}{ Cats } & $\begin{array}{l}\text { Marschner et al. }(2010) \\
(\mathrm{n}=15)(\mathrm{ST}: 30 \mathrm{~min})\end{array}$ & $2.4-9.5$ & $1.2-3.9$ & $45.5-73.5$ & $46.8-66.1$ \\
\hline & $\begin{array}{l}\text { Banerjee et al. }(2011) \\
(\mathrm{n}=20)(\mathrm{ST}: 30 \mathrm{~min})\end{array}$ & $0.5-7.8$ & $1.1-5.8$ & $43.8-71.4$ & $34.8-63.9$ \\
\hline Horses & $\begin{array}{l}\text { Hyldahl Laursen et al. }(2013) \\
(\mathrm{n}=20)(\mathrm{ST}: 30-60 \mathrm{~min})\end{array}$ & $7.25-16.65$ & $2.3-5.55$ & $34.1-58.75$ & $48.55-60.8$ \\
\hline Pigtail macaques & $\begin{array}{l}\text { Fong et al. }(2012) \\
(\mathrm{n}=50)(\mathrm{ST}:<3 \mathrm{~h})\end{array}$ & $1.99-4.39$ & $0.67-1.03$ & $74.42-82.62$ & $58.81-78.89$ \\
\hline
\end{tabular}


Table 5. Median (25th, 75th percentile values in parentheses) for kaolin-activated thromboelastography parameters determined in recalcified citrated whole blood of cows in 3 lactation periods (A to $\mathrm{C})^{1}$

\begin{tabular}{lcccc}
\hline Parameter $^{2}$ & $\mathrm{~A}(\mathrm{n}=24)$ & $\mathrm{B}(\mathrm{n}=16)$ & $\mathrm{C}(\mathrm{n}=20)$ & All $(\mathrm{n}=60)$ \\
\hline $\mathrm{R}(\min )$ & $4.0(3.2,4.4)$ & $4.1(3.0,4.9)$ & $4.0(3.2,4.9)$ & $4.0(3.1,4.8)$ \\
$\mathrm{K}(\min )$ & $1.0(0.8,1.2)$ & $1.0(0.8,1.3)$ & $1.0(0.8,1.2)$ & $1.0(0.8,1.2)$ \\
Angle $\alpha\left({ }^{\circ}\right)$ & $74.4(70.7,78.1)$ & $75.5(72.1,78.6)$ & $75.4(73.6,78.6)$ & $75.2(72.0,78.5)$ \\
MA $(\mathrm{mm})$ & $82.4(79.3,84.8)$ & $85.0(82.3,86.5)$ & $82.9(80.3,84.1)$ & $83.0(80.3,85.6)$ \\
$\mathrm{G}\left(\mathrm{dyn} / \mathrm{cm}^{2}\right)$ & $23.5(19.1,27.8)$ & $28.3(23.3,32.4)$ & $24.3(20.3,26.5)$ & $24.5(20.3,29.7)$ \\
\hline
\end{tabular}

${ }^{1}$ Group $\mathrm{A}=\leq 30 \mathrm{~d}$ postcalving, group $\mathrm{B}=31-99 \mathrm{~d}$ postcalving, group $\mathrm{C}=\geq 100 \mathrm{~d}$ postcalving.

${ }^{2} \mathrm{R}=$ reaction time; $\mathrm{K}=$ coagulation time; $\mathrm{MA}=$ maximum amplitude; $\mathrm{G}=$ clot rigidity

Age was not significantly different between the 3 lactation groups. The mean $( \pm \mathrm{SD})$ of the TEG parameters as well as coagulation parameters (PT, APPT, fibrinogen, plasma protein, plasma protein:fibrinogen ratio, platelet count, and packed cell volume) from the 3 lactation groups are shown in Tables 6 and 7, respectively.

\section{Stability Study}

The number of samples used in stability trials in the literature ranged from 8 to 30 (Bowbrick et al., 2000; Camenzind et al., 2000; Zambruni et al., 2004; Wiinberg et al., 2005; Hughes et al., 2007; Leclere et al., 2009). The number of samples in this study (28) was, although low, compatible with these studies.

Comparing the 2 -h time point with time group 1 $(\leq 48 \mathrm{~h})$ and time group $2(>48 \mathrm{~h})$, using the Wilcoxon signed rank test, showed that only $\mathrm{R}$ (reaction time) decreased significantly from the 2 -h time point to time group 2. No other significant differences were detected between the 2 groups. Over the whole period of $100 \mathrm{~h}$, all samples showed values within the reference interval with the exception of 2 single values of $\mathrm{R}$ that were slightly outside the lower range (at 50 and $75 \mathrm{~h}$ ).

The majority of the reported stability studies were performed with storage times ranging from $30 \mathrm{~min}$ to $4 \mathrm{~h}$ (Bowbrick et al., 2000; Zambruni et al., 2004; Wiinberg et al., 2005; Leclere et al., 2009). Only 2 studies have investigated storage times up to $72 \mathrm{~h}$ (Camenzind et al., 2000; Hughes et al., 2007). Although Hughes et al. (2007) did not find any significant differences up to $72 \mathrm{~h}$, Camenzind et al. (2000) reported significant differences at $24 \mathrm{~h}$ of storage for $\mathrm{K}$ and angle $\alpha$, at $48 \mathrm{~h}$ for MA value, and at $72 \mathrm{~h}$ for $\mathrm{R}$, all compared with the 1-h postsampling values. These results are in contrast to those of our study, where only $\mathrm{R}$ differed significantly; additionally, this change was observed after $48 \mathrm{~h}$ in our study instead of $72 \mathrm{~h}$ in that of Camenzind et al. (2000; Table 7).

Overall, the TEG parameters appear stable up to 48 $\mathrm{h}$ in cows, which would reflect the typical time period for transportation between sampling and analyzing. The reaction time $\mathrm{R}$ seems to be the first parameter to change after storage longer than $48 \mathrm{~h}$.

\section{Limitations}

One limitation of this study was that the samples were taken over different seasons, with possible effects of seasonal diet and health status. The reported reference intervals are valid only for adult Holstein-Friesian dairy cows. Falco et al. (2012) showed significantly different values for calves compared with adult cows. Given the reported significant differences between greyhound and non-greyhound parameters in dogs (Vilar et al., 2008), establishment of reference intervals for other cattle breeds may be necessary.

Table 6. Median (25th, 75th percentile values in parentheses) for coagulation parameters determined in citrated plasma of cows in 3 lactation periods $)^{1}$

\begin{tabular}{lcccc}
\hline Parameter $^{2}$ & $\mathrm{~A}(\mathrm{n}=24)$ & $\mathrm{B}(\mathrm{n}=16)$ & $\mathrm{C}(\mathrm{n}=20)$ & All $(\mathrm{n}=60)$ \\
\hline PT $(\mathrm{s})$ & $24.2(22.6,25.2)$ & $25.4(24.3,28.2)$ & $23.7(22.2,24.4)$ & $24.3(22.6,25.7)$ \\
APTT (s) & $54.2(45.7,60.7)$ & $50.0(45.9,55.4)$ & $48.4(44.1,52.7)$ & $50.1(44.8,57.0)$ \\
Fibrinogen $(\mathrm{F})(\mathrm{g} / \mathrm{L})$ & $4.5(4.0,6.0)^{\mathrm{a}}$ & $5.0(4.0,6.0)$ & $4.0(3.0,4.3)^{\mathrm{c}}$ & $4.0(4.0,5.0)$ \\
Plasma protein $(\mathrm{PP})(\mathrm{g} / \mathrm{L})$ & $63.5(60.0,66.0)^{\mathrm{a}}$ & $72.0(64.8,73.3)^{\mathrm{b}}$ & $70.0(66.0,70.3)^{\mathrm{c}}$ & $66.5(63.8,71.0)$ \\
PP:F ratio & $14.1(11.3,16.1)^{\mathrm{a}}$ & $14.4(12.2,18.0)$ & $17.8(15.7,23.3)^{\mathrm{c}}$ & $14.9(12.7,18.0)$ \\
Platelets $\left(\times 10^{9} / \mathrm{L}\right)$ & $318.0(233.0,391.0)$ & $313.0(228.0,362.5)$ & $305.0(258.0,348.5)$ & $313.0(235.3,371.5)$ \\
PCV $(\%)$ & $29.0(25.8,30.3)$ & $26.5(25.0,29.3)$ & $30.0(27.5,31.0)$ & $29.0(25.0,31.0)$ \\
\hline
\end{tabular}

${ }^{\mathrm{a}-\mathrm{c}}$ Means within a row with different superscripts differ $(P<0.017)$.

${ }^{1}$ Group $\mathrm{A}=\leq 30 \mathrm{~d}$ postcalving, group $\mathrm{B}=31-99 \mathrm{~d}$ postcalving, group $\mathrm{C}=\geq 100 \mathrm{~d}$ postcalving.

${ }^{2} \mathrm{PT}=$ prothrombin time; $\mathrm{APTT}=$ activated partial thromboplastin time; $\mathrm{PCV}=$ packed cell volume. 
Table 7. Median (25th, 75th percentile values) for the storage test, showing the kaolin-activated thromboelastography parameters determined in recalcified citrated whole blood of cows at $2 \mathrm{~h}$ postsampling and after $\leq 48$ and $>48 \mathrm{~h}$ of storage time (ST) at room temperature

\begin{tabular}{lccc}
\hline Parameter $^{1}$ & $\begin{array}{c}2 \mathrm{~h} \\
(\mathrm{n}=28)\end{array}$ & $\begin{array}{c}\text { Time group 1: ST } \leq 48 \mathrm{~h} \\
(\mathrm{n}=26)\end{array}$ & $\begin{array}{c}\text { Time group 2: ST }>48 \mathrm{~h} \\
(\mathrm{n}=11)\end{array}$ \\
\hline $\mathrm{R}(\min )$ & $3.9(3.1,4.8)^{\mathrm{a}}$ & $3.9(3.1,4.8)$ & $3.2(2.8,3.8)^{\mathrm{b}}$ \\
$\mathrm{K}(\mathrm{min})$ & $1.0(0.8,1.2)$ & $1.0(0.8,1.2)$ & $0.9(0.8,1.0)$ \\
Angle $\alpha$ & $75.7(73.9,77.6)$ & $75.7(73.9,77.6)$ & $75.9(75.5,77.1)$ \\
$\mathrm{MA}(\mathrm{mm})$ & $83.7(81.9,86.2)$ & $83.7(81.9,86.2)$ & $78.0(76.7,81.7)$ \\
$\mathrm{G}\left(\right.$ dyn $\left./ \mathrm{cm}^{2}\right)$ & $25.7(22.5,31.2)$ & $25.7(22.5,31.2)$ & $17.8(16.5,22.3)$ \\
\hline${ }^{\mathrm{a}, \mathrm{b}}$ Means within a row with different superscripts differ $(P=0.017)$. \\
${ }^{1} \mathrm{R}=$ reaction time; $\mathrm{K}=$ coagulation time; MA = maximum amplitude; $\mathrm{G}=$ clot rigidity.
\end{tabular}

Because of the small number of pregnant cows (15 out of 60 cows) in the current study, statistical analysis could not be performed to evaluate significant differences between pregnant versus nonpregnant cows. Additionally, the stability test was performed on only a few samples (albeit comparable with the number used in other studies); a greater number of samples as well as precisely set time points for a stability study would be preferred.

\section{Applications}

Thromboelastography could prove useful in bovine practice given the occurrence of coagulopathies as well as other diseases and clinical settings in cows. Of the diseases in other species that have been studied with thromboelastography and shown significant changes, several are relevant in cattle (e.g., DIC, hepatic disease, amyloidosis). Furthermore, thromboelastography could be helpful in investigation of bleeding disorders, especially those with unchanged plasma coagulation parameters (PT and APTT); for example, those due to platelet dysfunction (Simmental hereditary thrombopathy, Chediak-Higashi syndrome), and in early detection of hypercoagulopathies. Overall, however, further studies are necessary to assess the diagnostic value of thromboelastography in cows and to determine whether potential applications are similar to these observed in other species.

\section{ACKNOWLEDGMENTS}

The authors thank T. J. McKinley (Department of Veterinary Medicine, University of Cambridge, UK) for help with the statistics, and Corinna Weber (Laboklin GmbH \& Co. KG, Bad Kissingen, Germany) for corrections of the manuscript and professional help in bovine medicine. The stability study was presented at the congress of the European College of Veterinary Clinical Pathology and European Society of Veterinary Clinical Pathology in Berlin, Germany, in 2013.

\section{REFERENCES}

Banerjee, A., S. L. Blois, and R. D. Wood. 2011. Comparing citrated native, kaolin-activated, and tissue factor-activated samples and determining intraindividual variability for feline thromboelastography. J. Vet. Diagn. Invest. 23:1109-1113. http://dx.doi. org $/ 10.1177 / 1040638711425595$.

Bauer, N., O. Eralp, and A. Moritz. 2009. Establishment of reference intervals for kaolin-activated thromboelastography in dogs including an assessment of the effects of sex and anticoagulant use. J. Vet. Diagn. Invest. 21:641-648. http://dx.doi. org $/ 10.1177 / 104063870902100508$.

Bell, C. 2011. Bleeding disorders in cattle. In Pract. 33:106-115. http://dx.doi.org/10.1136/inp.d1194.

Borrelli, A., C. Bellino, E. Bozzetta, B. Bruno, S. Falco, C. Maurella, P. Gianella, M. Pezzolato, A. Cagnasso, and A. D'Angelo. 2013. Thromboelastometry in veal calves to detect hemostatic variations caused by low doses of dexamethasone treatment. BMC Vet. Res. 9:55.

Bowbrick, V. A., D. P. Mikhailidis, and G. Stansby. 2000. The use of citrated whole blood in thromboelastography. Anesth. Analg. 90:1086-1088. http://dx.doi.org/10.1097/00000539-20000500000015 .

Camenzind, V., T. Bombeli, B. Seifert, M. Jamnicki, D. Popovic, T. Pasch, and D. R. Spahn. 2000. Citrate storage affects Thrombelastograph analysis. Anesthesiology 92:1242-1249. http://dx.doi. org/10.1097/00000542-200005000-00011.

Donahue, S., and C. Otto. 2005. Thromboelastography: A tool for measuring hypercoagulability, hypocoagulability, and fibrinolysis. J. Vet. Emerg. Crit. Care 15:9-16. http://dx.doi.org/10.1111/ j.1476-4431.2005.04025.x.

Falco, S., B. Bruno, A. Borrelli, A. Cagnasso, and A. D'Angelo. 2012. Validation of thromboelastometry in cattle. Pages 91-96 in Veterinary Science. A. Pugliese, A. Gaiti, and C. Boiti, ed. SpringerVerlag, Berlin, Germany. 10.1007/978-3-642-23271-8_15.

Flint, S. K., A. C. G. Abrams-Ogg, S. A. Kruth, A. M. Bersenas, and R. D. Wood. 2011. Independent and combined effects of prednisone and acetylsalicylic acid on thromboelastography variables in healthy dogs. Am. J. Vet. Res. 72:1325-1332. http://dx.doi. org/10.2460/ajvr.72.10.1325.

Flint, S. K., R. D. Wood, A. C. G. Abrams-Ogg, S. A. Kruth, and A. Bersenas. 2012. Comparison of citrated native and kaolin-activated samples for thrombelastographic analysis in healthy dogs. J. Vet. Clin. Pathol. 41:249-255. http://dx.doi.org/10.1111/j.1939165X.2012.00431.x.

Fong, D. L., J. C. Ha, and C. E. Hotchkiss. 2012. Thromboelastography values from pigtail macaques (Macaca nemestrina): Effects of age and sex. J. Am. Assoc. Lab. Anim. Sci. 51:94-100.

Geffré, A., D. Concordet, J.-P. Braun, and C. Trumel. 2011. Reference Value Advisor: A new freeware set of macroinstructions to calculate reference intervals with Microsoft Excel. Vet. Clin. Pathol. 40:107-112. http://dx.doi.org/10.1111/j.1939-165X.2011.00287.x.

Gentry, P. A., R. M. Liptrap, and W. D. Black. 1979. Changes in blood coagulation profiles of dairy cows during pregnancy and in 
heifer calves after hormone treatment. Can. J. Anim. Sci. 59:503510. http://dx.doi.org/10.4141/cjas79-063.

Hartert, H. 1948. Blutgerinnungsstudien mit der Thrombelastographie, einem neuen Untersuchungsverfahren (Coagulation analysis with thrombelastography, a new method). Klin. Wochenschr. 26:577-583. http://dx.doi.org/10.1007/BF01697545.

Heuwieser, W., M. Biesel, and E. Grunert. 1989. Physiological coagulation profile of dairy cattle. Zentralbl. Veterinarmed. A 36:2431. http://dx.doi.org/10.1111/j.1439-0442.1989.tb00698.x.

Heuwieser, W., J. Kautni, M. Biesel, and E. Grunert. 1990a. Coagulation profile of dairy cattle in the periparturient period. Zentralbl. Veterinarmed. A 37:8-15. http://dx.doi. org/10.1111/j.1439-0442.1990.tb00870.

Heuwieser, W., J. Kautni, and E. Grunert. 1990b. Coagulation profile in different stages of pregnancy and under consideration of placental expulsion in dairy cattle. Zentralbl. Veterinarmed. A 37:310-315. http://dx.doi.org/10.1111/j.1439-0442.1990.tb00910.

Hughes, J. D., V. W. Macdonald, and J. R. Hess. 2007. Warm storage of whole blood for 72 hours. Transfusion 47:2050-2056. http:// dx.doi.org/10.1111/j.1537-2995.2007.01429.x.

Hyldahl Laursen, S., P. H. Andersen, M. Kjelgaard-Hansen, and B. Wiinberg. 2013. Comparison of components of biological variation between 3 equine thromboelastography assays. J. Vet. Clin. Pathol. 42:443-450. http://dx.doi.org/10.1111/vcp.12079.

Kol, A., and D. L. Borjesson. 2010. Application of thrombelastography/ thromboelastometry to veterinary medicine. Vet. Clin. Pathol. 39:405-416. http://dx.doi.org/10.1111/j.1939-165X.2010.00263.x.

Leclere, M., J.-P. Lavoie, M. Dunn, and C. Bédard. 2009. Evaluation of a modified thrombelastography assay initiated with recombinant human tissue factor in clinically healthy horses. J. Vet. Clin. Pathol. 38:462-466. http://dx.doi.org/10.1111/j.1939165X.2009.00157.x.

Marschner, C. B., C. Bjørnvad, A. Kristensen, and B. Wiinberg. 2010. Thromboelastography results on citrated whole blood from clinically healthy cats depend on modes of activation. Acta Vet. Scand. 52:38. http://dx.doi.org/10.1186/1751-0147-52-38.

McSherry, B. J., F. D. Horney, and J. J. de Groot. 1970. Plasma fibrinogen level in normal and sick cows. Can. J. Comp. Med. 34:191-197.
Nielsen, V. G. 2007. A comparison of the Thromboelastograph and the ROTEM. Blood Coagul. Fibrinolysis 18:247-252. http://dx.doi. org/10.1097/MBC.0b013e328092ee05.

Riley, J. H., and E. D. Lassen. 1979. Activated coagulation times of normal cows. J. Vet. Clin. Pathol. 8:31-33. http://dx.doi. org/10.1111/j.1939-165X.1979.tb00879.x.

Schlerka, G., and W. Baumgartner. 1994. Untersuchungen über die Blutgerinnung beim gesunden und kranken Rind. (Studies on blood coagulation in healthy and sick cattle). Pages 1277-1281 in Proc. XXVI Congress of the Italian Association of Buiatrics XVIII World Buiatrics Congress, Bologna, Italy.

Solberg, H. E. 2004. The IFCC DOI: Recommendation on estimation of reference intervals. The RefVal program. Clin. Chem. Lab. Med. 42:710-714. http://dx.doi.org/10.1515/CCLM.2004.121.

Vilar, P., C. G. Couto, N. Westendorf, C. Iazbik, J. Charske, and L. Marin. 2008. Thromboelastographic tracings in retired racing Greyhounds and in non-Greyhound dogs. J. Vet. Intern. Med. 22:374-379. http://dx.doi.org/10.1111/j.1939-1676.2008.0061.x.

Wiinberg, B., A. L. Jensen, R. Rojkjaer, P. Johansson, M. KjelgaardHansen, and A. T. Kristensen. 2005. Validation of human recombinant tissue factor-activated thromboelastography on citrated whole blood from clinically healthy dogs. J. Vet. Clin. Pathol 34:389-393. http://dx.doi.org/10.1111/j.1939-165X.2005.tb00066.

Wiinberg, B., and A. T. Kristensen. 2010. Thromboelastography in veterinary medicine. Semin. Thromb. Hemost. 36:747-756. http://dx.doi.org/10.1055/s-0030-1265291.

Wittek, T., A. Grosche, L. Locher, A. Alkaassem, and M. Fürll. 2010. Biochemical constituents of peritoneal fluid in cows. Vet. Rec. 166:15-19. http://dx.doi.org/10.1136/vr.b5584.

Zambruni, A., U. Thalheimer, G. Leandro, D. Perry, and A. K. Burroughs. 2004. Thromboelastography with citrated blood: Comparability with native blood, stability of citrate storage and effect of repeated sampling. Blood Coagul. Fibrinolysis 15:103-107. http://dx.doi.org/10.1097/01.mbc.0000114364.44793.84. 